\title{
Assessment of Hemodynamic Effects of Etomidate versus Propofol in Elective Surgical Patients - A Clinical Study
}

\author{
Lokesh Kumar Gupta ${ }^{1}$, Keshav Dev Jagar ${ }^{2}$ \\ ${ }^{1}$ Associate professor, Department of Anaesthesiology, Saraswathi Institute of Medical Sciences, Hapur, Uttar Pradesh, India 245304, ${ }^{2}$ Assistant Professor, \\ Department of Anaesthesiology, Saraswathi Institute of Medical Sciences, Hapur, Uttar Pradesh, India 245304.
}

\section{Abstract}

Background: Hemodynamic stability during laryngoscopy and intubation with minimal side effects is the main objective of any anaesthetist. The present study was conducted to assess hemodynamic effects of etomidate versus propofol in elective surgical patients. Subjects and Methods: The present study was conducted on 48 patients planned for elective surgery of both genders. Patients were divided into 2 groups of 24 each. Group I patients were given propofol (P) and group II were given the etomidate. Parameters were recorded. Results: The mean height in group I patients was $165.2 \mathrm{~cm}$ and in group II was $166.7 \mathrm{~cm}$, mean weight was $68.1 \mathrm{~kg}$ in group I and $65.2 \mathrm{~kg}$ in group II. Mean MAP (mm $\mathrm{Hg}$ ) at T1 in group I was 118, T2 was 90, T3 was 102 and T4 was 106. In group II, T1 was 110, T2 was 94, T3 was 98 and T4 was 100. The difference was non- significant (P>0.05). Mean HR (beats/min) at T1 in group I was 77.2, T2 was 79.4, T3 was 81.5 and T4 was 79.1. In group II at T1 was 75.4, T2 was 81.6, at T3 was 87.2 and at T4 was 84.3. No statistical significance was observed in between both the groups on comparing Heart Rate and Mean Arterial Pressure. Conclusion: Both Etomidate and Propofol are equally effective in terms of their hemodynamic effects.

Keywords: Etomidate, Hemodynamic, Propofol.

Corresponding Author: Dr. Keshav Dev Jagar, Assistant Professor, Department of Anaesthesiology, Saraswathi Institute of Medical Sciences, Hapur, Uttar Pradesh, India 245304.

Received: September 2019

Accepted: October 2019

\section{Introduction}

Hemodynamic stability during laryngoscopy and intubation with minimal side effects is the main objective of any anaesthetist. $^{[1]}$ Pressor response to laryngoscopy is due to receptors present at the tongue base that get stimulated, catecholamines rise in levels of adrenaline and noradrenaline, stimulation of the laryngeal and tracheal receptors. ${ }^{[2]}$ The arterial pressure may rise to $20-25 \mathrm{mmHg}$ and peak is usually seen $30-35$ seconds after laryngoscopy. On one hand, laryngoscopy leads to sympathetic responses leading to tachyarrhythmias and hypertension increased intracranial tension and greater myocardial workload. On the other hand, induction agents cause vasodilation and obliteration of autonomic nervous system leading to hypotension. ${ }^{[3]}$

Etomidate is a carboxylated imidazole derivative, has a rapid onset (10-12sec) and a brief duration of action, and hydroxylases primarily in liver. It provides hemodynamic stability in both noncardiac and cardiac disease patients after dosage of 0.15 to $0.30 \mathrm{mg} / \mathrm{kg}$. It directly inhibits 11-beta hydroxylation, which results in temporary reduction in biosynthesis of cortisol and aldosterone with serum concentrations in minimum limit of normal range. ${ }^{[4]}$

Propofol, an alkylphenol derivative, provides rapid onset and short duration of action. It causes considerable reduction in systemic vascular resistance and arterial pressure $15 \%$ to $40 \%$ after iv induction with $2 \mathrm{mg} / \mathrm{kg}$. Its effect on $\mathrm{HR}$ is variable. It causes direct myocardial depression at doses above $0.75 \mathrm{mg} / \mathrm{kg}{ }^{[5]}$ The present study was conducted to assess hemodynamic effects of etomidate versus propofol in elective surgical patients.

\section{Subjects and Methods}

The present study was conducted in the department of Anesthesia. It comprised of 48 patients planned for elective surgery of both genders. All were informed regarding the study. Ethical approval was obtained from institute prior to the study.

General information such as name, age, gender etc. was recorded. Patients were divided into 2 groups of 24 each. Group I patients were given propofol $(\mathrm{P})$ and group II were given the etomidate. All patients were pre medicated with intramuscular injection of morphine $0.1 \mathrm{mg} / \mathrm{kg}$ and promethazine $0.5 \mathrm{mg} / \mathrm{kg}$ half hour prior to induction of anesthesia.

Patient was monitored with Heart Rate, pulse oximetry electrocardiogram (5-lead ECG), end tidal carbon- dioxide (EtCO2), Non-invasive blood pressure (NIBP). Anaesthetic agent for induction was prepared by an independent 
0

colleague. Anaesthesia was induced with either propofol (Diprivan, Astra Zeneca, Cheshire, United Kingdom) 2 $\mathrm{mg} / \mathrm{kg}$ or etomidate (Etomidat-Lipuro 2\%, B. Braun, Melsungen, Germany) $0.5 \mathrm{mg} / \mathrm{kg}$. Endotracheal intubation was facilitated with rocuronium bromide (Roger, Cardilla health care, Mumbai) in the dose of $0.1 \mathrm{mg} / \mathrm{kg}$ in a single attempt less than 20 seconds. Mechanical ventilation was instituted to maintain eucapnia. Anesthesia was maintained with titrated doses of sevoflurane. Analgesia was attained with fentanyl up to a total dose of $10 \mu \mathrm{g} / \mathrm{kg}$. Parameters were recorded before induction (T1), after induction (T2), after intubation (T3), and 7 minutes after intubation (T4).

Hypotension (MAP $\leq 55 \mathrm{~mm} \mathrm{Hg}$ ) was treated with incremental doses of phenylephrine. Hypertension (MAP $\geq 100 \mathrm{~mm} \mathrm{Hg}$ ) was treated with fentanyl $1 \mu \mathrm{g} / \mathrm{kg}$ up to three times and then with a nitroglycerine infusion (10-100 $\mu \mathrm{g} / \mathrm{kg}$ ). Bradycardia (HR $\leq 40 \mathrm{~min}$ ) was treated with atropine $0.5 \mathrm{mg}$ up to three times, and thereafter with ephedrine $5 \mathrm{mg}$. Tachycardia (HR $\geq 90 \mathrm{~min}$ ) was treated with fentanyl $1 \mu \mathrm{g} / \mathrm{kg}$ up to three times and thereafter with metoprolol $1 \mathrm{mg}$ bolus dose. Parameters were recorded. Results thus obtained were subjected to statistical analysis. $\mathrm{P}$ value less than 0.05 was considered significant.

\section{Results}

Table 1: Distribution of patients

\begin{tabular}{|l|l|l|}
\hline Groups & Group I & Group II \\
\hline Agent & Propofol & Etomidate \\
\hline Number & 24 & 24 \\
\hline
\end{tabular}

[Table 1] shows that group I patients were given Propofol and group II patients were given Etomidate.

\section{Table 2: Basic characteristics}

\begin{tabular}{|l|c|c|c|}
\hline Characteristics & Group I & Group II & P value \\
\hline Height $(\mathrm{cm})$ & 165.2 & 166.7 & 0.25 \\
\hline Weight $(\mathrm{Kg})$ & 68.1 & 65.2 & 0.14 \\
\hline Gender ratio (M:F) & $18: 6$ & $20: 4$ & 1.00 \\
\hline
\end{tabular}

[Table 2], graph I shows that mean height in group I patients was $165.2 \mathrm{~cm}$ and in group II was $166.7 \mathrm{~cm}$, mean weight was $68.1 \mathrm{~kg}$ in group I and $65.2 \mathrm{~kg}$ in group II. The difference was non- significant $(\mathrm{P}>0.05)$.

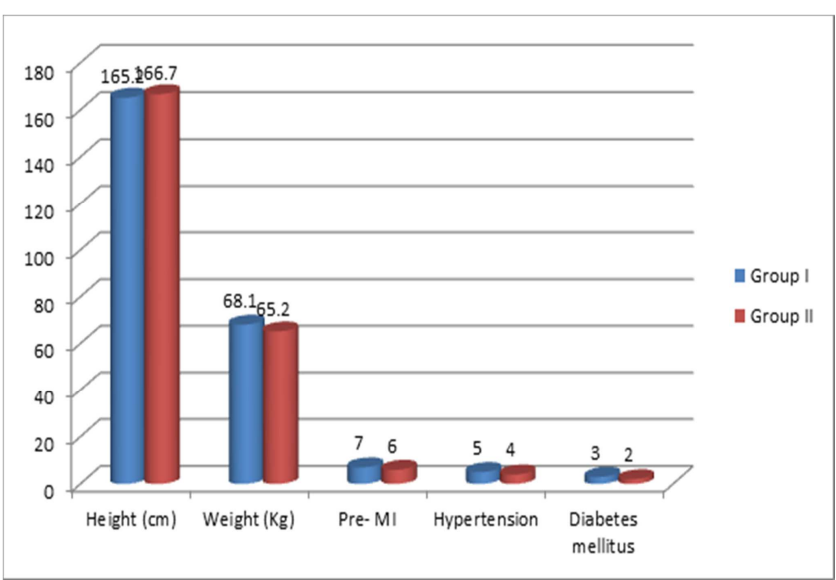

Figure 1: Basic characteristics

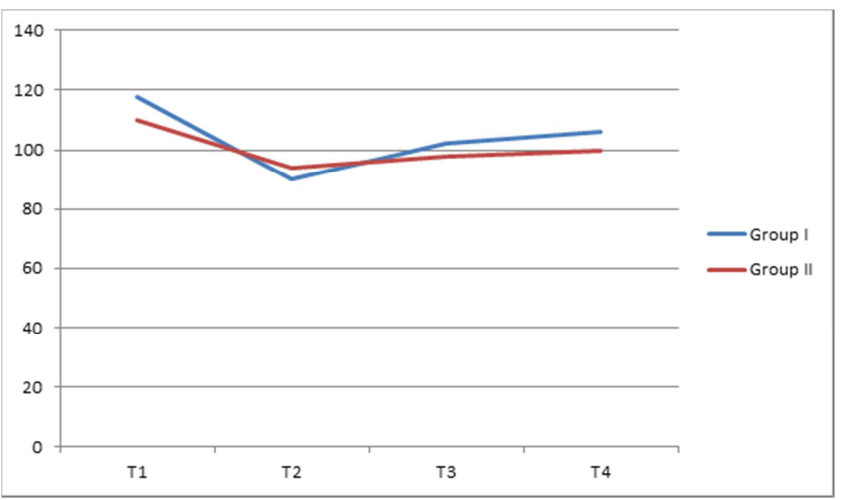

Figure 2: Comparison of MAP in both groups

[Figure 2] shows that mean MAP $(\mathrm{mm} \mathrm{Hg})$ at $\mathrm{T} 1$ in group I was $118, \mathrm{~T} 2$ was $90, \mathrm{~T} 3$ was 102 and T4 was 106. In group II, T1 was $110, \mathrm{~T} 2$ was $94, \mathrm{~T} 3$ was 98 and T4 was 100 . The difference was non- significant $(\mathrm{P}>0.05)$.

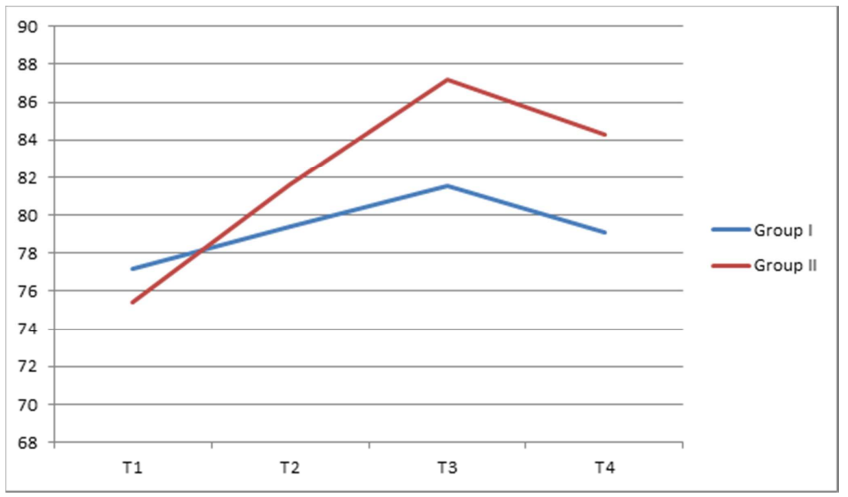

Figure 3: Comparison of Heart rate (HR)

[Figure 3] shows that mean HR (beats/min) at T1 in group I was 77.2, T2 was 79.4, T3 was 81.5 and $\mathrm{T} 4$ was 79.1 . In group II at T1 was 75.4 , T2 was 81.6 , at T3 was 87.2 and at T4 was 84.3.

\section{Discussion}

More than $60 \%$ of all emergency airway interventions use etomidate as the bolus induction agent owing to its favourable hemodynamic properties and ease of dosing. Data from the National Emergency Airway Registry (NEAR) show that etomidate is the most commonly used induction agent for emergency airway intervention. ${ }^{[6]}$ Benzodiazepines were used $18 \%$ of the time and were the next most common agents used. Hemodynamic changes are well tolerated in normal individuals but may be life threatening in cardiac patients and patients of increased intracranial pressure. Criado A et al, ${ }^{[7]}$ studied the hemodynamic effects of etomidate induction in 36 patients. Their results showed SV (Stroke volume), MAP (Mean arterial pressure), and LVW (Left ventricular work) significantly reduced but the heart rate increased significantly. They concluded that although etomidate has a negative inotropic effect, the variables remained within acceptable limits. The present study was conducted to assess hemodynamic effects of etomidate versus propofol in elective surgical patients. 
In this study, group I patients were given Propofol and group II patients were given Etomidate.

Bruessel et $\mathrm{al}^{[8]}$ found that sixty patients in age group of 1850 years of ASA grade I and II were divided randomly into two groups of thirty patients each. Hemodynamic data was observed and compared. Sample size was taken for convenience. Statistically significant difference was found in heart rate $(p=0.000$ at induction; $p=0.0001$ at 1 min after intubation) and MAP in both the groups at $0 \mathrm{~min}(\mathrm{p}=0.0008)$ and after 1 minute $(\mathrm{p}=0.004)$ of induction with hemodynamic parameters significantly higher in etomidate group than the etofol group. There was no statistically significant difference at 2 mins, 5 mins, 10 mins, 20 mins, 30 mins and 60 mins between the two groups.

The mean height in group I patients was $165.2 \mathrm{~cm}$ and in group II was $166.7 \mathrm{~cm}$, mean weight was $68.1 \mathrm{~kg}$ in group I and $65.2 \mathrm{~kg}$ in group II.

We found that mean MAP $(\mathrm{mm} \mathrm{Hg})$ at $\mathrm{T} 1$ in group I was 118, T2 was 90, T3 was 102 and T4 was 106. In group II, T1 was $110, \mathrm{~T} 2$ was $94, \mathrm{~T} 3$ was 98 and T4 was 100 . The difference was non- significant. Ghafoor et al ${ }^{[9]}$ reported the effects of etomidate on duration of mechanical ventilation. There was significant statistical heterogeneity in this comparison. They employed a random-effects model for meta-analysis, describing the MD and $95 \%$ CI. The pooled result of 315 patients receiving etomidate, compared to 306 patients receiving other induction agents, showed no significant difference in the duration of mechanical ventilation.

We observed that mean HR (beats/min) at T1 in group I was 77.2 , T2 was 79.4, T3 was 81.5 and T4 was 79.1. In group II at T1 was 75.4, T2 was 81.6 , at T3 was 87.2 and at T4 was 84.3. Bruder et al ${ }^{[10]}$ reported the effects of etomidate on SOFA score. Statistical heterogeneity was not calculated. The pooled result of 234 patients receiving etomidate, compared to 235 patients receiving other induction agents, showed a significant difference in the SOFA score (MD0.70; $95 \%$ CI 0.01 to 1.39 ) favoring other induction agents over etomidate.

\section{Conclusion}

Both Etomidate and Propofol are equally effective in terms of their hemodynamic effects. Further studies are required for these drugs when used synergistically with adequate doses of opioids and benzodiazepines.

\section{References}

1. Saricaoglu F, Uzun S, Arun O, et al. A clinical comparison of etomidate-lipuro, propofol and admixture at induction. Saudi J Anaesth 2011;5(1):62- 6 .

2. Weisenberg M, Sessler DI, Tavdi M, et al. Dose-dependent hemodynamic effects of propofol induction following brotizolam premedication in hypertensive patients taking angiotensin-converting enzyme inhibitors. J Clin Anesth 2010;22(3):190-5.

3. Lim YS, Kang DH, Kim SH, et al. The cardiovascular effects of midazolam co-induction to propofol for induction in aged patients. Korean J Anesthesiol 2012;62(6):536-42.

4. Reves JG, Glass PSA, Lubarsky DA, et al. Intravenous nonopioid anesthetics. In: Miller RD, edr. Miller's Anesthesia. 6th edn. Philadelphia: Churchill Livingstone 2005: p. 317-78.

5. Canbay O, Celebi N, Arun O, et al. Efficacy of intravenous acetaminophen and lidocaine on propofol injection pain. Br J Anaesth 2008;100(1):95-8.

6. Güzelmeriç F, Erdoğan HB, Koçak T. Kardiyak acillerde anestezik yaklaşım. Türk Göğüs Kalp Damar Cer Derg 2007;15(1):82-9.

7. Yağan Ö, Taș N, Küçük A, et al. Haemodynamic responses to tracheal intubation using propofol, etomidate and etomidate-propofol combination in anaesthesia induction. J Cardiovasc Thorac Res 2015;7(4):134-40.

8. Bruessel T, Theissen JL, Vigfusson G: Hemodynamic and cardiodynamic effects of propofol and etomidate: Negative inotropic propeties of propofol. Anaeth Analg. 1989; 69: 35-40.

9. Ghafoor HB, Afshan G, Kamal R. General anaesthesia with laryngeal mask airway: Etomidate vs propofol for hemodynamic stability. Open J Anaesthesiol 2012; 2: 161-5.

10. Bruder EA, Ball I, Ridi S, Pickett W, Hohl C. Single induction dose of etomidate versus other induction agents for endotracheal intubation in critically ill patients. Cochrane Database of Systematic Reviews 2012, Issue 11.

Copyright: () the author(s), publisher. Academia Anesthesiologica International is an Official Publication of "Society for Health Care \& Research Development". It is an open-access article distributed under the terms of the Creative Commons Attribution Non-Commercial License, which permits unrestricted non-commercial use, distribution, and reproduction in any medium, provided the original work is properly cited.

How to cite this article: Gupta LK, Jagar KD. Assessment of Hemodynamic Effects of Etomidate versus Propofol in Elective Surgical Patients - A Clinical Study. Acad. Anesthesiol. Int. 2019;4(2):320-22.

DOI: dx.doi.org/10.21276/aan.2019.4.2.72

Source of Support: Nil, Conflict of Interest: None declared. 